\title{
Estimation of genetic diversity in a natural population of cambui tree (Myrciaria tenella O. Berg) using ISSR markers
}

J.G.S. Santana ${ }^{1}$, A.L.S. Nascimento ${ }^{2}$, T.S. Costa ${ }^{2}$, T.M.B. de Almeida ${ }^{2}$, A.R.C. Rabbani ${ }^{3}$ and A.V.C. Silva ${ }^{2}$

${ }^{1}$ Programa de Pós-Graduação em Agricultura e Biodiversidade, Universidade Federal de Sergipe, São Cristovão, SE, Brasil

${ }^{2}$ Embrapa Tabuleiros Costeiros, Aracaju, SE, Brasil

${ }^{3}$ Instituto Federal da Bahia, Porto Seguro, BA, Brasil

Corresponding author: A.V.C. Silva

E-mail: ana.veruska@embrapa.br

Genet. Mol. Res. 15 (4): gmr.15048819

Received May 17, 2016

Accepted July 12, 2016

Published October 5, 2016

DOI http://dx.doi.org/10.4238/gmr.15048819

Copyright (C) 2016 The Authors. This is an open-access article distributed under the terms of the Creative Commons Attribution ShareAlike (CC BY-SA) 4.0 License.

\begin{abstract}
Cambui (Myrciaria tenella O. Berg) is a native species from Brazil, which belongs to the family Myrtaceae. Molecular characterization is one of the most used tools for the study of the biotechnological potential of species because the diversity level between individuals can be inferred. Analysis of genetic diversity is fundamental to the direction of the strategies necessary to form and maintain a germplasm. This study aimed to evaluate the genetic diversity in a natural population of cambui using inter-simple sequence repeat (ISSR) molecular markers. The natural population, which provided the plant material, is found at the Private Reserve of Natural Heritage of Caju, which belongs to the experimental field of Embrapa Tabuleiros Costeiros, in the municipality of Itaporanga d'Ajuda, SE, Brazil.
\end{abstract}


Young leaves of each individual were collected for DNA extraction and analysis of PCR-ISSR. Thirty primers were tested and the top 10 were selected. The use of these primers resulted in 71 fragments with $98.3 \%$ polymorphism. Similarity of individuals ranged between 0.30 and 0.92 . The most similar individuals were $\mathrm{C} 13$ and $\mathrm{C} 17$ and the most distant were $\mathrm{C} 1$ and $\mathrm{C} 41$. Through UPGMA, six distinct groups were identified. This information may be used for conservation of these genetic resources, germplasm exchange, creation of germplasm bank and in future studies with this species.

Key words: Myrtaceae; Native fruits; Molecular markers; Conservation

\section{INTRODUCTION}

Brazil has the distinction of possessing between 15 and $20 \%$ of all global biodiversity and has the largest number of endemic species. These species are mainly concentrated in the Amazon and in two of the nineteen world hotspots (Atlantic Forest and Cerrado) (Ganem, 2010). Although biodiversity is extremely important for the maintenance of natural ecological processes and for human activities, recent estimates show a significant decline in biodiversity and suggest that species extinctions will be concentrated in the hotspots where the threat of habitat loss is higher (Joppa et al., 2011).

Myrtaceae species are found on almost all continents. This family includes more than 140 genera and 5800 species of trees and shrubs (Govaerts et al., 2016). In Brazil, especially in regions dominated by the Atlantic Forest, trees of the Myrtaceae family are the woody plant of greater biological importance because they are predominant members of this biome (Gressler et al., 2006). However, ecosystem fragmentation has occurred because of the substantial increase of deforestation, the expansion of agricultural and livestock activities, the exploitation of trees, and population growth. This fragmentation is limited to small patches or isolated fragments that replace forest cover. Thus, species endemic to the Atlantic Forest biome have been rapidly disappearing (Morellato and Haddad, 2000).

In Sergipe, the forest cover of the Atlantic Forest currently is $7.47 \%$ of its original area (Jesus et al., 2014). Several native fruit trees have great potential for use, and some studies of these species have been conducted in Sergipe (Costa et al., 2011; Rabbani et al., 2012).

Several species of native plants have disappeared without any basic knowledge of them ever being known, such as some species of the Myrtaceae family, which are included in lists of endangered species in Brazil (Landrum and Kawasaki, 1997; Machado et al., 2005). Therefore, conservation strategies of these resources are crucial, and research on ecology, genetics, reproduction, physiology, biogeography, botany, and anthropology is required (Pádua and Ferreira, 2008).

Among the native fruits from Brazil, cambui (Myrciaria tenella O. Berg), which belongs to the Myrtaceae family, is a little known native fruit, and it mostly occurs in natural areas. Its potential has not yet been exploited, and it may be a source of food and various compounds (Pinheiro et al., 2011). Although Lorenzi (2000) suggests the species has potential for landscape and timber use, its production is not yet widespread. In contrast, there are other species of the Myrtaceae family, which have high economic value, such as guava (Psidium guajava L.), jabuticaba [Myrciaria cauliflora (Mart.) O. Berg.], and Surinam cherry (Eugenia

Genetics and Molecular Research 15 (4): gmr.15048819 
uniflora L.), which are commercially exploited (Landrum and Kawasaki, 1997).

The conservation of plant genetic resources is a complex multidisciplinary task, which involves several steps, such as the obtainment of germplasm, characterization, evaluation, documentation, conservation, and use of genetic resources (Pádua and Ferreira, 2008).

One of the means used to promote the conservation of genetic resources is the assessment of genetic diversity, which enables the degree of genetic variability to be known and evaluated. This information is fundamental in the formation of germplasms and in the identification of new genes of interest. Thus, molecular markers have been a biotechnological tool widely used for providing information at the DNA level. This study evaluated genetic diversity in a natural population of cambui trees using inter-simple sequence repeat (ISSR) molecular markers.

\section{MATERIAL AND METHODS}

\section{Plant material}

Young leaves of 50 cambui (Figure 1) were collected in a native population in May 2015. The population is located in the Private Reserve of Natural Heritage of Caju, which belongs to the experimental field of Embrapa Tabuleiros Costeiros in the municipality of Itaporanga d'Ajuda, SE $\left(11.116585^{\circ} \mathrm{S}, 37.186742^{\circ} \mathrm{W}\right)$ (Figure 2). The area is typical restinga, and the soil is a Humiluvic Spodosol. Leaves were removed from the trees, wrapped in labeled plastic bags, and transported in coolers to the Laboratory of Molecular Biology of Embrapa Tabuleiros Costeiros in Aracaju. The material was stored at $-80^{\circ} \mathrm{C}$ before DNA extraction.

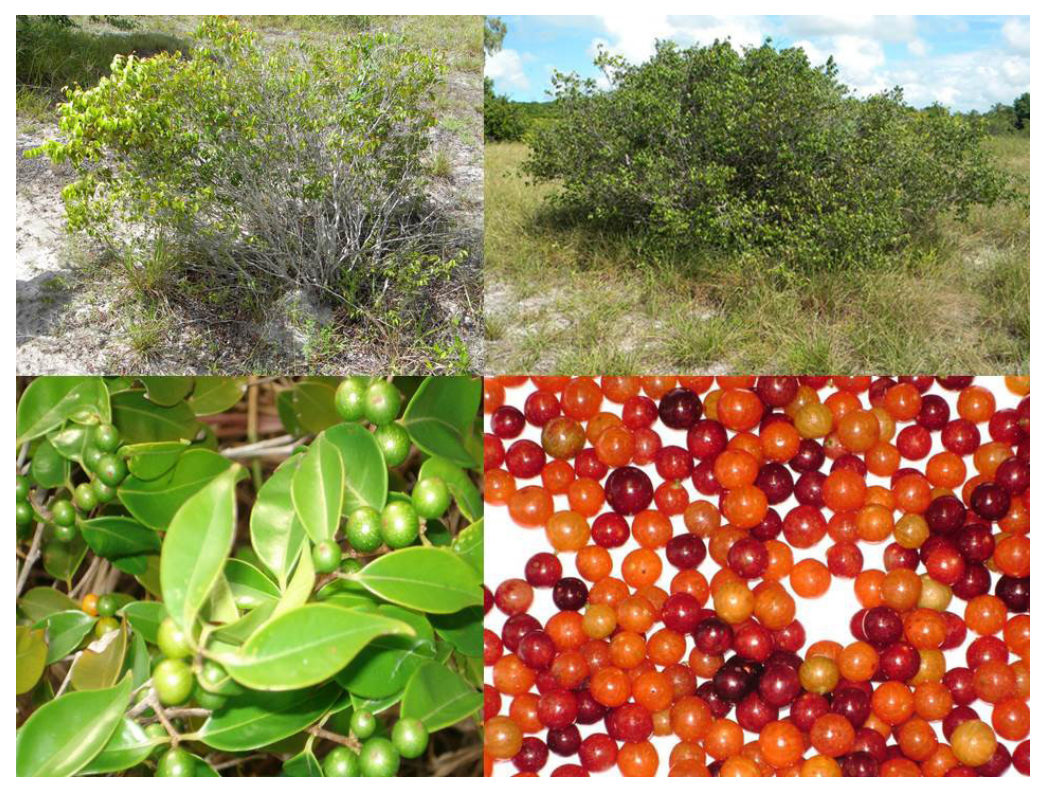

Figure 1. Tree and fruits of cambui (Myrciaria tenella O. Berg). Embrapa Tabuleiros Costeiros, 2016. 


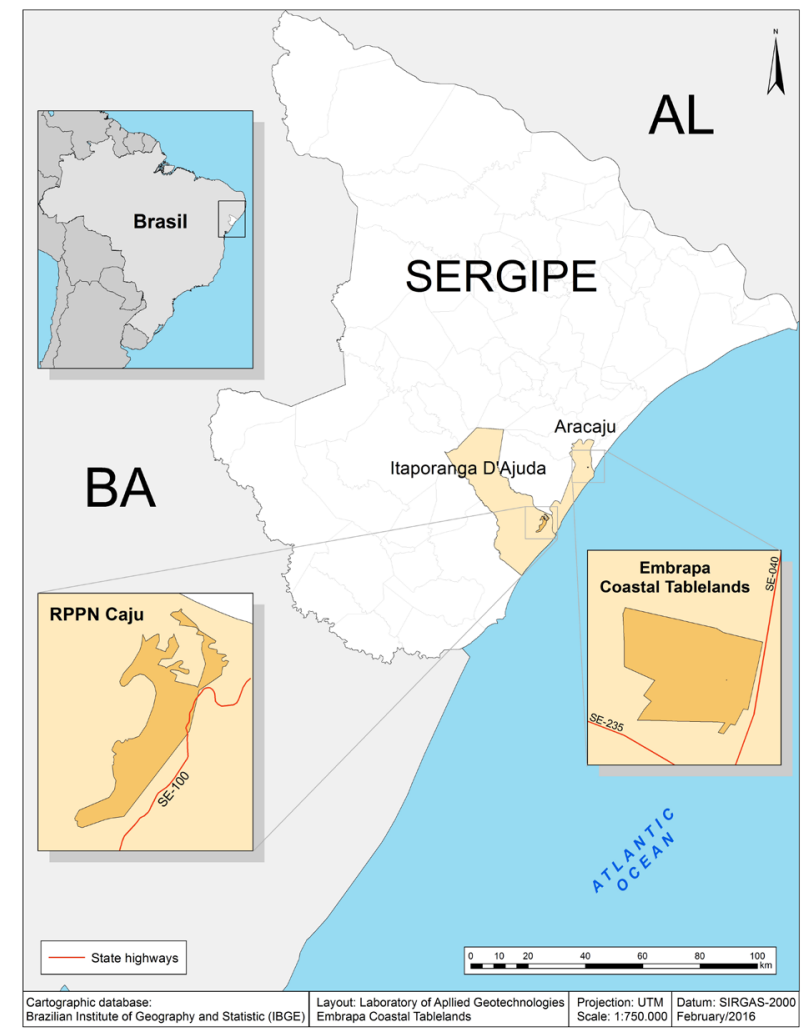

Figure 2. Location of the studied natural population of cambui. Reserva Particular do Patrimônio Natural (RPPN) of Caju, Itaporanga d'Ajuda, SE, Brazil. Embrapa Tabuleiros Costeiros, 2016.

\section{DNA extraction}

Leaves $(1 \mathrm{~g})$ were used for DNA extraction according to the methodology of Romano and Brasileiro (1999). After preheating at $65^{\circ} \mathrm{C}, 1 \mathrm{~mL} 2 \%$ CTAB extraction buffer $(5 \mathrm{M} \mathrm{NaCl}$, $1 \mathrm{M}$ Tris $\mathrm{HCl}, \mathrm{pH} 8.0,0.5 \mathrm{M}$ EDTA) was added to the pulverized leaf material, along with 2 $\mu \mathrm{L} \beta$-mercaptoethanol and $3 \mu \mathrm{L} \mathrm{K}$ proteinase $(10 \mathrm{mg} / \mathrm{mL})$. Samples were incubated at $65^{\circ} \mathrm{C}$ for $30 \mathrm{~min}$ and then allowed to rest for $30 \mathrm{~min}$. Initially, extractions were performed with $500 \mu \mathrm{L}$ chloroform/isoamyl alcohol (24:1), followed by $400 \mu \mathrm{L}$ ice-cold isopropanol, and the stored overnight at $-20^{\circ} \mathrm{C}$. The obtained precipitate was washed three times, two washes with $70 \%$ ethanol and one with $100 \%$ ethanol. After drying, DNA was resuspended in $44 \mu \mathrm{L}$ TE buffer (100 mM Tris-HCl, pH 7.4, $1 \mathrm{mM}$ EDTA), treated with $6 \mu \mathrm{L} \mathrm{RNAse}(20 \mathrm{mg} / \mathrm{mL})$, and incubated at $37^{\circ} \mathrm{C}$ for $30 \mathrm{~min}$.

\section{Electrophoresis, DNA quantification, and dilution}

Evaluation of DNA quality was determined by electrophoresis on a $0.8 \%$ agarose gel, loaded with $2 \mu \mathrm{L}$ each sample, $8 \mu \mathrm{L}$ MilQ sterile water, and $2 \mu \mathrm{L}$ loading solution $(0.01 \%$ bromophenol blue, $40 \%$ glycerol). Horizontal electrophoresis was conducted for $45 \mathrm{~min}$ at 
$76 \mathrm{~V}, 38 \mathrm{~mA}$, and $120 \mathrm{~W}$. Subsequently, the gel was stained in ethidium bromide solution for about 40 min and then it was documented with a Gel Doc L-pix HE (Loccus Biotecnologia, Brazil). Concentrations of DNA samples were determined using the NanoDrop 2000c (Thermo Scientific, USA) software. DNA working solutions $(10 \mathrm{ng} / \mathrm{mL})$ were prepared by diluting the samples in TE buffer and then were stored at $-20^{\circ} \mathrm{C}$.

\section{Testing and selection of ISSR primers}

Thirty primers were tested on $2 \%$ agarose gels (Table 1 ). Each test reaction included $1 \mu \mathrm{L}$ genomic DNA $(10 \mathrm{ng} / \mu \mathrm{L}), 1.0 \mu \mathrm{L}$ each primer $(5 \mathrm{mM}), 14.8 \mu \mathrm{L}$ MilQ sterile water, $2 \mu \mathrm{L}$ $10 \mathrm{X}$ reaction buffer, $0.6 \mu \mathrm{L} \mathrm{MgCl}_{2}, 0.4 \mu \mathrm{L}$ dNTP $(10 \mathrm{nM})$, and 0.2 Taq polymerase $(5 \mathrm{U} / \mu \mathrm{L})$ in a total volume of $20 \mu \mathrm{L}$. The ideal annealing temperatures varied between $44.6^{\circ}$ and $57.2^{\circ} \mathrm{C}$.

Table 1. ISSR primers, their respective sequences, and annealing temperatures (At).

\begin{tabular}{|c|c|c|}
\hline Primers & Sequence (5'-3') & At $\left({ }^{\circ} \mathrm{C}\right)$ \\
\hline UBC 807 & AGA GAG AGA GAG AGA GT & 47.0 \\
\hline UBC 809 & AGA GAG AGA GAG AGA GG & 57.2 \\
\hline UBC 810 & GAG AGA GAG AGA GAG AT & 45.4 \\
\hline UBC 811 & GAG AGA GAG AGA GAG AC & 46.8 \\
\hline UBC 812 & GAG AGA GAG AGA GAG AA & 55.8 \\
\hline UBC 813 & CTC TCT CTC TCT CTC TT & 44.6 \\
\hline UBC 815 & CTC TTC TCT CTC TCT CTG & 47.6 \\
\hline UBC 816 & CAC ACA CAC ACA CAC AT & 55.8 \\
\hline UBC 817 & CAC ACA CAC ACA CAC AA & 50.3 \\
\hline UBC 818 & CAC ACA CAC ACA CAC AG & 57.2 \\
\hline UBC 820 & GTG TGT GTG TGT GTG TC & 47.5 \\
\hline UBC 823 & TCT CTC TCT CTC TCT CC & 57.2 \\
\hline UBC 826 & ACA CAC ACA CAC ACA CC & 57.2 \\
\hline UBC 828 & TGT GTG TGT GTG TGT GA & 54.8 \\
\hline UBC 834 & AGA GAG AGA GAG AGA GYT & 45.6 \\
\hline UBC 835 & AGA GAG AGA GAG AGA GYC & 50.2 \\
\hline UBC 841 & GAG AGA GAG AGA GAG AYC & 48.5 \\
\hline UBC 843 & CTC TCT CTC TCT CTC TRA & 56.5 \\
\hline UBC 845 & CTC TCT CTC TCT CTC TRG & 48.1 \\
\hline UBC 848 & CAC ACA CAC ACA CAC ARG & 52.7 \\
\hline UBC 851 & GTG TGT GTG TGT GTG TYG & 49.2 \\
\hline UBC 855 & ACA CAC ACA CAC ACY T & 53.1 \\
\hline UBC 856 & ACA CAC ACA CAC ACA CYA & 56.5 \\
\hline UBC 857 & ACA CAC ACA CAC ACY G & 58.8 \\
\hline UBC 858 & TGT GTG TGT GTG TGT GRT & 56.5 \\
\hline UBC 864 & ATG ATG ATG ATG ATG ATG & 50.8 \\
\hline UBC 878 & GGA TGG ATG GAT GGA & 53.4 \\
\hline ISSR 2 & CTC TCT CTC TCT CTC TAC & 51.5 \\
\hline ISSR 3 & CTC TCT CTC TCT CTC TTG & 51.5 \\
\hline ISSR 5 & CTC TCT CTC TCT CTC TGC & 51.5 \\
\hline
\end{tabular}

\section{Polymerase chain reaction (PCR), electrophoresis, and documentation}

PCR was performed with $1 \mu \mathrm{L}$ genomic DNA $(10 \mathrm{ng} / \mathrm{uL}), 1.0 \mu \mathrm{L}$ each primer $(5 \mathrm{mM})$, 14.8 $\mu \mathrm{L}$ Milli-Q sterilized water, $2 \mu \mathrm{L} 10 \mathrm{X}$ reaction buffer, $0.6 \mu \mathrm{L} \mathrm{MgCl}_{2}, 0.4 \mu \mathrm{L}$ dNTP $(10$ $\mathrm{nM})$, and 0.2 Taq polymerase $(5 \mathrm{U} / \mu \mathrm{L})$ in a total volume of $20 \mu \mathrm{L}$. Templates were amplified in a Proflex ${ }^{\circledR}$ Applied biosystems thermocycler (Foster City, CA, USA) with denaturation at $94^{\circ} \mathrm{C}$ for 4 min, followed by 37 amplification cycles. Each cycle included denaturation at $94^{\circ} \mathrm{C}$ for $45 \mathrm{~s}$, annealing for $45 \mathrm{~s}$, and extension at $72^{\circ} \mathrm{C}$ for 2 min. After the reaction cycles, there was a final extension at $72^{\circ} \mathrm{C}$ for $7 \mathrm{~min}$, followed by cooling at $4^{\circ} \mathrm{C}$. Reaction

Genetics and Molecular Research 15 (4): gmr.15048819 
products were electrophoresed on $2 \%$ agarose gels at $250 \mathrm{~V}, 145 \mathrm{~mA}$, and $120 \mathrm{~W}$ for $3 \mathrm{~h}$. For size standardization of bands, $10 \mu \mathrm{L} \mathrm{100-bp} \mathrm{molecular} \mathrm{weight} \mathrm{marker} \mathrm{was} \mathrm{used.} \mathrm{The} \mathrm{gel} \mathrm{was}$ stained in ethidium bromide solution for about $40 \mathrm{~min}$. Subsequently, results were documented using a Gel Doc L-pix HE (Loccus Biotecnologia).

\section{Identification of the optimal number of bands}

In order to verify if the number of generated markers was enough to analyze the sample group of 50 genotypes, bootstrap simulations were conducted with resampling of different sizes with each simulation replicated 5000 times using the DBoot software (Coelho, 2001).

\section{Data analysis}

The absence (0) or presence (1) of fragments on each gel was visually analyzed, and a binary matrix was generated. Binary data were used in all the following tests. Estimates of genetic similarities were obtained from the binary matrix using the Jaccard coefficient with the FreeTree software (Pavlícek et al., 1999). Genetic diversity parameters, such as number of observed alleles, effective number of alleles, Nei's genetic diversity, and Shannon index, were calculated using the Genalex 6.3 software (Peakall and Smouse, 2006). The total number of alleles $\left(N_{\mathrm{A}}\right)$, the effective number of alleles $\left(N_{\mathrm{E}}\right)$, and the expected heterozygosity $\left(H_{\mathrm{E}}\right)$ were obtained following the methodology of Lynch and Milligan (1994) and Maguire et al. (2002). The Shannon genetic diversity index $(I)$ was obtained using the procedure of Brown and Weir (1983). The dendrogram was generated with the UPGMA algorithm (unweighted pair group method with arithmetic mean) using Treeview software based on the Jaccard coefficient. To examine clustering, 10,000 bootstraps were performed using TreeView software (Page, 1996). Principal coordinates analysis (PCoA) was performed with the Genalex 6.3 software, using the Jaccard coefficient obtained from the FreeTree software (Pavlícek et al., 1999).

\section{RESULTS and DISCUSSION}

Among the 30 tested primers, 10 provided informative and polymorphic bands. In the amplification of samples, 71 loci were generated of which 70 were polymorphic (98.3\%), varying from 4 (UBC 820) to 10 loci (UBC 848) per primer (Table 2).

Table 2. List of ISSR primers, total number of fragments, number of polymorphic fragments, percentage of polymorphic fragments, and range of bp generated by PCR for the study of genetic diversity among individuals of a population of cambui.

\begin{tabular}{l|c|c|c|c}
\hline Primers & Number of fragments & Number of polymorphic fragments & Polymorphism (\%) & bp range \\
\hline UBC 807 & 7 & 7 & 100 & $500-1650$ \\
\hline UBC 813 & 7 & 7 & 100 & $850-2000$ \\
\hline UBC 818 & 7 & 7 & 100 & $500-2000$ \\
\hline UBC 820 & 4 & 4 & 100 & $850-2000$ \\
\hline UBC 834 & 6 & 6 & 100 & $1000-3000$ \\
\hline UBC 835 & 9 & 9 & 100 & $850-2000$ \\
\hline UBC 841 & 7 & 7 & 100 & $500-1000$ \\
\hline UBC 845 & 7 & 7 & 100 & $400-2000$ \\
\hline UBC 848 & 10 & 10 & 100 & $500-3000$ \\
\hline ISSR 3 & 7 & 6 & 85 & $850-2000$ \\
\hline- & 71 & 70 & 98.3 & - \\
\hline
\end{tabular}

Genetics and Molecular Research 15 (4): gmr.15048819 
Several studies using ISSR markers have successfully obtained polymorphisms allowing the evaluation of genetic divergence. Silva et al. (2014) found 123 polymorphic bands using 12 primers in a study on the diversity and genetic structure of jenipapo (Genipa americana L.). Lorenzoni et al. (2014) evaluated the genetic divergence of 16 biriba accessions [Rollinia mucosa (Jacq.) Baill] and obtained 118 polymorphic bands using 13 primers. Santana et al. (2011) characterized the genetic variability between umbu-cajazeira accessions (Spondias sp) from the Germplasm Bank of Tropical Fruits of Embrapa Cassava and Fruits and obtained 201 polymorphic bands using 25 primers. Jimenez et al. (2015) evaluated the diversity of 38 mangaba (Hancornia speciosa Gomes) individuals from natural populations in the state of Pernambuco and obtained 83 polymorphic bands using six primers.

In Myrtaceae, Oliveira et al. (2014) analyzed the genetic distance between accessions of guava and araça trees of the Psidium genus, belonging to the Germplasm Bank of the Universidade Estadual do Norte Fluminense, and obtained 216 polymorphic bands using 17 primers. In an additional study with guava, Nogueira et al. (2014) used 18 microsatellite markers in populations from Espírito Santo and Minas Gerais and found that there is genetic diversity among and within populations. Mani et al. (2011), in studies carried out in India on the association of morphological and molecular characterization by ISSR and RAPD between species of the Psidium genus, obtained 234 polymorphic bands using 31 ISSR primers.

In other economically important crops, the use of ISSR markers was also successful. Dhanorkar et al. (2005) obtained 96 polymorphic bands in the analysis of genetic relationships between grape varieties (Vitis spp) using 13 primers. Kar et al. (2008) studied the variability of mulberry (Morus spp) and obtained 85 polymorphic bands using 14 primers.

The number of polymorphic bands is considered to be optimum when the coefficient of variation is less than $1 \%$. According to Silva et al. $(2013,2014)$, there is a directly proportional relationship between the number of fragments generated and the coefficient of variation $(\mathrm{CV} \%)$, with a decrease in variation associated with an increase in the number of fragments (Figure 3). In this study, CV\% stabilized beyond 60 fragments suggesting that the fragments used in this study (71) can be used for diversity analysis.

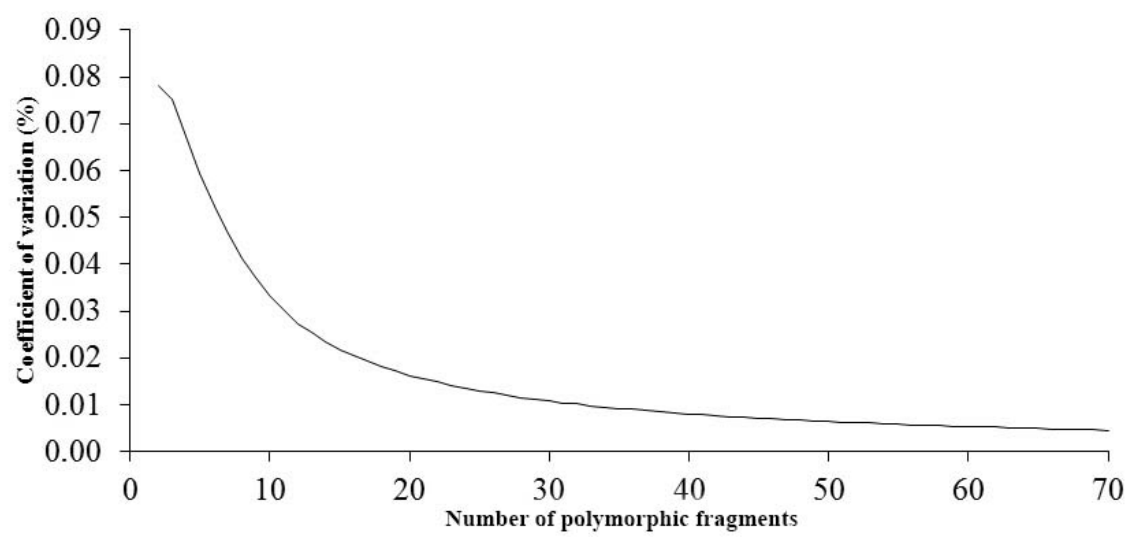

Figure 3. Coefficient of variation $(\mathrm{CV} \%)$ as a function of the number of fragments in 50 individuals of cambui (Myrciaria tenella O. Berg) based on genetic similarities obtained by the bootstrap method with 5000 resamplings.

Genetics and Molecular Research 15 (4): gmr.15048819 
The total $N_{\mathrm{E}}$ ranged from 0.57 to 1.89 , and the $I$ values were 0.30 to 0.66 . Genetic diversity $(H)$ values ranged from 0.18 to 0.47 (Table 3 ). In this study, the $I$ value obtained was 0.52 . According to Padua and Ferreira (2008), the value of $I$ may vary between 0 and 1 , with a value of 1 indicating the maximum diversity of a population. Thus, the studied population possesses a considerable level of genetic diversity, which is a good candidate for population analysis using dominant (Dawson et al., 1995). In a study on genetic diversity in natural populations of buriti (Mauritia flexuosa), Rossi et al. (2014) found higher values for $I$ and $H$, when evaluating the distribution of genetic diversity between versus within populations.

Table 3. Number of alleles $\left(N_{\mathrm{A}}\right)$, effective number of alleles $\left(N_{\mathrm{E}}\right)$, Shannon index $(I)$, and genetic diversity $(H)$ in the study of genetic diversity of a population of cambui (Myrciaria tenella O. Berg) using ISSR markers, where total represents the mean of each column.

\begin{tabular}{l|c|c|c|c}
\hline Primer & $N_{\mathrm{A}}$ & $N_{\mathrm{E}}$ & $\mathrm{I}$ & $\mathrm{H}$ \\
\hline UBC 807 & 2 & 1.80 & 0.63 & 0.44 \\
\hline UBC 813 & 2 & 1.89 & 0.66 & 0.47 \\
\hline UBC 818 & 2 & 1.42 & 0.43 & 0.27 \\
\hline UBC 820 & 2 & 1.69 & 0.54 & 0.60 \\
\hline UBC 834 & 2 & 1.73 & 0.51 & 0.42 \\
\hline UBC 835 & 2 & 1.55 & 0.46 & 0.34 \\
\hline UBC 841 & 2 & 1.52 & 0.52 & 0.30 \\
\hline UBC 845 & 2 & 1.56 & 0.57 & 0.35 \\
\hline UBC 848 & 2 & 0.57 & 0.30 & 0.39 \\
\hline ISSR 3 & 2 & 1.26 & 0.52 & 0.18 \\
\hline Total & 2 & 1.50 & & 0.35 \\
\hline
\end{tabular}

In contrast to our results, Chagas et al. (2015) found a low mean value of $I$ in the study of a palm population (Elaeis guineensis Jacq.) using ISSR markers and found low diversity between the analyzed individuals. Costa et al. (2011) observed low diversity between mangaba (Hancornia speciosa Gomes) accessions of Sergipe's germplasm bank, using the Shannon index based on molecular markers. Silva et al. (2016) evaluated diversity in commercial cupuaçu (Theobroma grandiflorum Schum.) and also found low values for the Shannon index and confirmed the uniformity of the crop.

Under natural conditions, the value of $H$ is never zero since individuals may incorporate new alleles through crossing even in small populations or in fragments, in addition to losses due to genetic drift (Silva et al., 2014).

The occurrence of diversity among the individuals studied using ISSR markers suggests the efficacy of this technique for the identification of diversity with the most divergent individuals within a given group being $\mathrm{C} 1$ and $\mathrm{C} 2$. Overall mean similarity was 0.58 . The lowest similarity was observed among individuals $\mathrm{C} 1$ and $\mathrm{C} 41(0.30)$, while the highest similarity was found among individuals $\mathrm{C} 13$ and $\mathrm{C} 17$ (0.92). The pairs of more similar individuals were $\mathrm{C} 26$ and $\mathrm{C} 28$ (0.80); $\mathrm{C} 6$ and $\mathrm{C} 7, \mathrm{C} 36$ and $\mathrm{C} 38$ (0.81); $\mathrm{C} 12$ and $\mathrm{C} 13, \mathrm{C} 12$ and $\mathrm{C} 14, \mathrm{C} 13$ and $\mathrm{C} 14, \mathrm{C} 17$ and $\mathrm{C} 19, \mathrm{C} 34$ and $\mathrm{C} 35, \mathrm{C} 34$ and $\mathrm{C} 36$ (0.82); $\mathrm{C} 8$ and $\mathrm{C} 9$ (0.83), $\mathrm{C} 17$ and $\mathrm{C} 18$ (0.84); $\mathrm{C} 12$ and $\mathrm{C} 17, \mathrm{C} 14$ and $\mathrm{C} 17, \mathrm{C} 19$ and $\mathrm{C} 20, \mathrm{C} 36$ and $\mathrm{C} 39$ (0.85); $\mathrm{C} 18$ and $\mathrm{C} 19$ (0.86), $\mathrm{C} 7$ and $\mathrm{C} 8(0,87)$; and $\mathrm{C} 5$ and $\mathrm{C} 17, \mathrm{C} 27$ and $\mathrm{C} 28$ (0.88).

Based on the Jaccard coefficient, six groups were identified by the UPGMA analysis (Figure 4). The most distant and different individuals are found in the G1 group, and C1 (0.31) and C41 (0.36) are totally isolated from other individuals. The largest group was G2 with 21 individuals, and the closest individuals were $\mathrm{C} 13$ and $\mathrm{C} 17$ (0.92). G3 had 12 individuals, and the pair of individuals $\mathrm{C} 46$ and $\mathrm{C} 47$ (0.88).

Genetics and Molecular Research 15 (4): gmr.15048819 


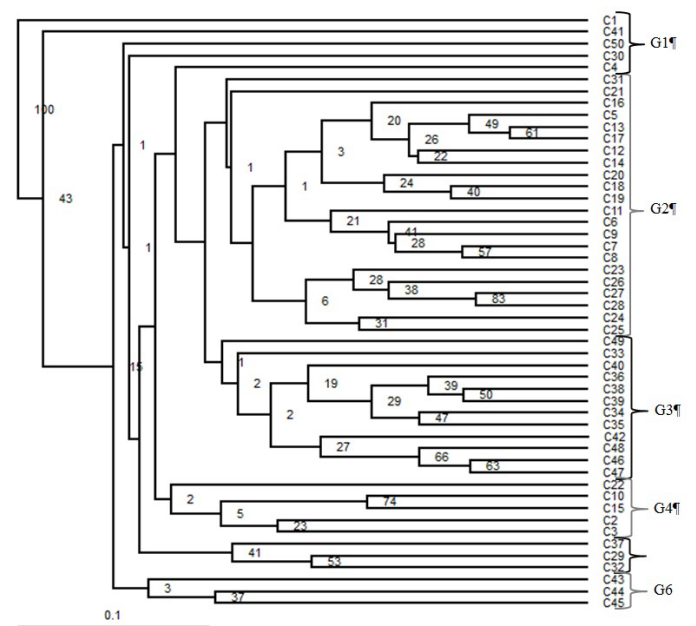

Figure 4. Phylogeny based on UPGMA estimated from the Jaccard coefficient (1908) of genetic similarity and bootstrap analysis $(10,000 \mathrm{X})$ for 50 individuals of a population of cambui (Myrciaria tenella O. Berg).

G4 has five individuals, with C22 (0.57 SJ) being the most distant. G5 and G6 groups were smaller with three genotypes each. A large distribution of genotypes was observed in most groups, indicating wide diversity between the evaluated genotypes. This high variability could be explained by the tendency of allogamy of species which have not yet been domesticated (Oliveira et al., 2009). This was also observed in the research of Santana et al. (2011), who found high variability between 17 umbu-cajazeira (Spondias sp) accessions, which is a species under domestication.

PCoA (Figure 5) was conducted to determine the genetic relationships between individuals minimizing variation. Eleven groups were formed in this clustering model and the subgroups were clear indicating greater differentiation of genotypes. Consistent with the UPGMA results, some pairs of individuals $(\mathrm{C} 10 / \mathrm{C} 15, \mathrm{C} 13 / \mathrm{C} 17, \mathrm{C} 24 / \mathrm{C} 25, \mathrm{C} 27 / \mathrm{C} 28, \mathrm{C} 46 / \mathrm{C} 47)$ were genetically close in the PCoA. This information is important for the establishment of an ex situ collection or a germplasm exchange, since in these cases, only one individual would be selected.

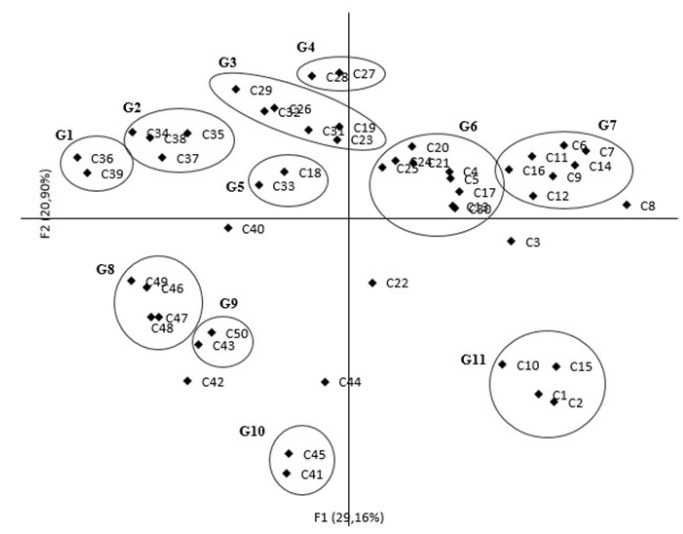

Figure 5. Principal coordinates analysis of 50 individuals of a population of cambui (Myrciaria tenella O. Berg).

Genetics and Molecular Research 15 (4): gmr.15048819 
The use of more than one grouping method, owing to the differences in hierarchical optimization and ordering of groups, enables the classification of individuals to be complemented by the criteria used by each technique, and prevents erroneous inferences from being adopted in the allocation of materials within a particular genotypic subgroup (Silva et al., 2011). The existence of high genetic variability was also observed by Pinheiro et al. (2011) using RAPD molecular markers in 20 individuals from a natural population of cambui in Sao Cristóvão, SE.

Knowledge of genetic diversity is fundamental for evolution, which results from changes in gene frequencies. In a germplasm collection, this information may provide useful data to assist in the conservation, management, and use of these genetic resources and may also help breeders to identify and select clones or relatives to establish a basic breeding program.

\section{CONCLUSIONS}

There is genetic diversity in the evaluated natural population of cambui. The level of genetic resolution and reliability obtained by the analysis using ISSR markers allowed the discrimination of genetically different genotypes, which may be used for the management of genetic resources of the species. For formation of ex situ germplasm collections and germplasm exchange, the genotypes $\mathrm{C} 1, \mathrm{C} 41, \mathrm{C} 50, \mathrm{C} 30$, and $\mathrm{C} 4$ are recommended owing to them being more genetically distant.

\section{Conflicts of interest}

The authors declare no conflict of interest.

\section{ACKNOWLEDGMENTS}

We thank CAPES for the Master's degree scholarship granted to the first author and the Embrapa Tabuleiros Costeiros for assisting with the study.

\section{REFERENCES}

Brown AHD and Weir BS (1983). Measuring genetic variability in plant populations. In: Isozymes in plant genetics and breeding, part A (Tanksley SD and Orton TJ, eds.). Elsevier Science Publishing, Amsterdam, 219-239.

Chagas KPT, Souza RF, Fajardo CG and Vieira FA (2015). Selection of ISSR markers and genetic diversity in a population of Elaeis guineensis. Agraria 10: 147-152. http://dx.doi.org/10.5039/agraria.v10i1a5133

Coelho ASG (2001). DBoot: avaliação dos erros associados a estimativas de distâncias/similaridades genéticas através do procedimento de bootstrap com número variável de marcadores, versão 1.1 (Software). UFG, Goiânia.

Costa TS, Silva AVC, Lédo AS, Santos ARF, et al. (2011). Genetic diversity of accessions of the mangaba germplasm bank in Sergipe, Brazil. Pesq. Agropec. Bras. 46: 499-507. http://dx.doi.org/10.1590/S0100-204X2011000500007

Dawson IKAJ, Simons AJ, Waugh R and Powell W (1995). Diversity and genetic differentiation among subpopulations of Gliricidia sepium revealed by PCR-based assays. Heredity 74: 10-18. http://dx.doi.org/10.1038/hdy.1995.2

Dhanorkar VM, Tamhankar SA, Patil SG and Rao VS (2005). ISSR-PCR for assessment of genetic relationship among grape varieties cultivated in India. Vitis 44: 127-131.

Ganem RS (2010). Conservação da biodiversidade: legislação e políticas públicas. Câmara dos Deputados, Brasília.

Govaerts R, Sobral M, Ashton P, Barrie F, et al. (2016). World checklist of Myrtaceae. Royal Botanic Gardens. Available at [http://apps.kew.org/wcsp/home.do]. Accessed February 2, 2016.

Gressler E, Pizo MA and Morellato LPC (2006). Pollination and seed dispersal of Brazilian Myrtaceae. Rev. Bras. Bot. Braz. J. Bot. 29: 509-530. http://dx.doi.org/10.1590/S0100-84042006000400002

Jesus JB, Gama DC and Fernandes MM (2014). Estudo da distribuição do bioma Mata Atlântica no Estado de Sergipe. In: Anais do VIII Simpósio Brasileiro de Pós-Graduação em Ciências Florestais. Recife.

Genetics and Molecular Research 15 (4): gmr.15048819 
Jimenez HJ, Martins LSS, Montarroyos AVV, Silva Junior JF, et al. (2015). Genetic diversity of the Neotropical tree Hancornia speciosa Gomes in natural populations in Northeastern Brazil. Genet. Mol. Res. 14: 2015. 10.4238.

Joppa LN, Roberts DL, Myers N and Pimm SL (2011). Biodiversity hotspots house most undiscovered plant species. Proc. Natl. Acad. Sci. USA 108: 13171-13176. http://dx.doi.org/10.1073/pnas.1109389108

Kar PK, Srivastava PP, Awasthi AK and Urs SR (2008). Genetic variability and association of ISSR markers with some biochemical traits in mulberry (Morus spp.) genetic resources available in India. Tree Genet. Genomes 4: 75-83. http://dx.doi.org/10.1007/s11295-007-0089-x

Landrum LR and Kawasaki ML (1997). The genera of Myrtaceae in Brazil: an illustrated synoptic treatment and identification keys. Brittonia 49: 508-536. http://dx.doi.org/10.2307/2807742

Lorenzi H (2000). Árvores Brasileiras. 3rd edn. Plantarum. São Paulo.

Lorenzoni RM, Soares TCB, Santiago VF and Coelho RI (2014). Using ISSR for fingerprinting accessions of biribazeiro. Rev. Bras. Frutic. 36: 251-257. http://dx.doi.org/10.1590/S0100-29452014000500029

Lynch M and Milligan BG (1994). Analysis of population genetic structure with RAPD markers. Mol. Ecol. 3: 91-99. http://dx.doi.org/10.1111/j.1365-294X.1994.tb00109.x

Machado ABM, Martins CS and Drummond GM (2005). Lista da fauna brasileira ameaçada de extinção: incluindo a lista das espécies quase ameaçadas e deficientes em dados. Fundação Biodiversitas, Belo Horizonte.

Maguire TL, Peakall R and Saenger P (2002). Comparative analysis of genetic diversity in the mangrove species Avicennia marina (Forsk.) Vierh. (Avicenniaceae) detected by AFLPs and SSRs. Theor. Appl. Genet. 104: 388-398. http:// dx.doi.org/10.1007/s001220100724

Mani A, Mishra R and Thomas G (2011). Elucidation of diversity among psidium species using morphological and SPAR methods. J. Phytol. 3: 53-61.

Morellato LPC and Haddad CFB (2000). The Brazilian Atlantic Forest: an introduction. Biotropica 32: 786-792. http:// dx.doi.org/10.1111/j.1744-7429.2000.tb00618.x

Nogueira AM, Ferreira MF, Guilhen JH and Ferreira A (2014). Multivariate analysis in a genetic divergence study of Psidium guajava. Genet. Mol. Res. 13: 10657-10668. http://dx.doi.org/10.4238/2014.December.18.8

Oliveira MG, Oliveira JG, Gomes Filho AG, Pereira MG, et al. (2009). Genetic diversity of barbados cherry (Malphigia emarginata D. C.), with RAPD molecular markers and morpho-agronomical characteristics. Rev. Bras. Frutic. 31 : 162-170. http://dx.doi.org/10.1590/S0100-29452009000100023

Oliveira NNS, Viana AP, Quintal SSR, Paiva CL, et al. (2014). Analysis of Genetic distance Between access of the Gender Psidium by route markers ISSR. Rev. Bras. Frutic. 31: 917-992. http://dx.doi.org/10.1590/0100-2945-413/13

Pádua JG and Ferreira FR (2008). Recursos genéticos de fruteiras. In: Fundamentos do melhoramento de fruteiras (Bruckner $\mathrm{CH}$, ed.). Editora UFV, Viçosa.

Page RDM (1996). TreeView: an application to display phylogenetic trees on personal computers. Comput. Appl. Biosci. 12: 357-358.

Pavlícek A, Hrdá S and Flegr J (1999). Free-Tree--freeware program for construction of phylogenetic trees on the basis of distance data and bootstrap/jackknife analysis of the tree robustness. Application in the RAPD analysis of genus Frenkelia. Folia Biol. 45: 97-99.

Peakall R and Smouse PE (2006). GENALEX 6: genetic analysis in Excel. Population genetic software for teaching and research. Mol. Ecol. Notes 6: 288-295. http://dx.doi.org/10.1111/j.1471-8286.2005.01155.x

Pinheiro LR, Almeida CS and Silva AVC (2011). Diversidade genética de uma população natural de cambuizeiro e avaliação pós-colheita de seus frutos. Sci. Plena 7: 1-5.

Rabbani ARC, Silva-Mann R and Ferreira RA (2012). Genetic variability of Genipa americana L. belonging to the lower course of São Francisco river. Rev. Arvore 36: 401-409. http://dx.doi.org/10.1590/S0100-67622012000300002

Romano E and Brasileiro ACM (1999). Extração de DNA de plantas. Biot. Ciênc. Desenvolv. 9: 40-43.

Rossi FS, Rossi AAB, Dardengo JDFE and Sebbenn AM (2014). Genetic diversity in natural populations of Mauritia flexuosa (Arecaceae) using ISSR markers. Sci. Forum 42: 631-639.

Santana IBB, Oliveira EJ, Soares Filho WS and Cunha Moreira RF (2011). Genetic variability among Umbu-Cajazeira accessions by ISSR markers. Rev. Bras. Frutic. 33: 868-876. http://dx.doi.org/10.1590/S0100-29452011005000090

Silva AVC, Santos ARF, Wickert E, Silva JFS, et al. (2011). Diversidade gentética entre acessos de mangabeira (Hancornia speciosa Gomes). Rev. Bras. Cienc. Agr. 6: 572-578.

Silva AVC, Rabbani ARC, Almeida CS and Clivati D (2013). Genetic structure and diversity of the neem germplasm bank from Brazil northeast. Afr. J. Biotechnol. 12: 2822-2829.

Silva AVC, Freire KCS, Lédo AS and Rabbani ARC (2014). Genetic variability of Genipa americana L. belonging to the lower course of São Francisco river. Sci. Agric. 71: 387-393. http://dx.doi.org/10.1590/0103-9016-2014-0038

Silva BM, Rossi AAB, Dardengo JDFE, de Araujo VAAC, et al. (2016). Genetic diversity estimated using intersimple sequence repeat markers in commercial crops of cupuassu tree. Cienc. Rural 46: 108-113. http://dx.doi. org/10.1590/0103-8478cr20141634

Genetics and Molecular Research 15 (4): gmr.15048819 